Portland State University

PDXScholar

\title{
A study of the crisis nature of the preparenthood period and implications for preventative social work practice
}

Julie Jean Colton

Portland State University

Follow this and additional works at: https://pdxscholar.library.pdx.edu/open_access_etds

Part of the Family, Life Course, and Society Commons, Psychology Commons, and the Social Work Commons

Let us know how access to this document benefits you.

\section{Recommended Citation}

Colton, Julie Jean, "A study of the crisis nature of the preparenthood period and implications for preventative social work practice" (1980). Dissertations and Theses. Paper 3449.

https://doi.org/10.15760/etd.5333

This Thesis is brought to you for free and open access. It has been accepted for inclusion in Dissertations and Theses by an authorized administrator of PDXScholar. Please contact us if we can make this document more accessible: pdxscholar@pdx.edu. 
A STUDY OF THE CRISIS NATURE OF THE PREPARENTHOOD PERIOD AND IMPLICATIONS FOR PREVENTATIUE SOCIAL WORK PRACIICE

\author{
by \\ JULIE JEAN COLTON
}

A research project submitted in partial fulfillment of the requirements for the degree of

\author{
MASTER \\ OF \\ SOCIAL WORK
}

Portland State University

1980 
I approve the research project of Julle Jean Colton presented July 25, 1980.

Nancy Kogolof', Assistant Professor 
TABLE OF CONTENTS

FAGE

CHAPTER

I INTRODUCTION . . . . . . . . . . . . 1

II REVIEW OF THE IITERATURE . . . . . . . . 3

W1despread Phenomenon of Maternal Anxiety ............ 3

Obstetric Complications Caused By

Maternal Anxiety . . . . . . . . 5

The Effectiveness of Prenatal

Education In Reducing Maternal

Anxiety

Effectiveness of Prenatal Education

In Reducing obstetric Complications.

Interfamilial Relationships . . . . 12

Evidence of Paternal Anxiety . . . . . 13

Preparenthood Education and

Counseling Needed . . . . . . 15

Stress In Marital Relations During

Preparenthood .......... 16

MaternaI-Infant Bonding is Important , . 18

Bonding Father with Mother and Infant . 20

Ch1ldbirth Education Classes . . . . 21

Fathers Present At Delivery . . . . 22

Effectiveness of Chlldbirth Education . 25

Counseling Durirg Preporenthood . . : 27

Ilimitations of Childbirth Education . . 30

Importance of Enotional Preparation

for Chliduirth ......... 31 
CHAPTER

PAGE

Negative Birth Experiences Related.

To Child Abuse ........ 32

The Preventative Role of Social Work . . 34

Besearch on Preventative Approach To

Family Therapy ......... 37

Preventative Education and Counseling

Needed............ 41

Conclusion ............ . . . 42

III A DESCRIPTION OF A MODEL PREPARENRHOOD CONSULTATION PROGRAM ........... 44

Rationale ............ . . 44

Concepts ............. . 47

Format and objectives ....... 49

IV CONCLUSION . . . . . . . . . . 52

REFERENCES .................. 55 


\section{CEAPTER I}

\section{INTRODUCTION}

This study addresses the preparenthood perlod of family life, that period from conception to six weeks after the infant is born. This period was of great interest because in nine years of social work practice I have recognized that families resist change after their particular fam11y system process, even destructive process, is estab11shed. I also belleve that the order, or disorder, of soclety depends upon the order of the institution of the family. Other institutions of soclety depend upon the family for their existence.

This investigation was undertaken to explore the following questions. Are most couples in our soclety adequately informed regarding the events of pregnancy, childb1rth and early parenthood? Are most couples prepared to meet the demands of and understand the personal and interpersonal changes imposed by these erents? I suspected that preparation would reduce the cocurrence of problems such as maternal anxiety, paternal anxlety, obstetric complications and poor marital relations.

I explored the preparenthood period through reviewing the literature, and through my own experience as a midwife, chlldbirth educator and mar1tal and fanily counselor. Most authorities agree that preparenthood is a major transitional 
crisis perlod of life for each individual's self-esteem, for the marital couple's relationship and for family ife.

I belleve that preventative social work intervention which focuses on education, constructive marital comminication and family process would benefit couples by reducing anxiety and, thereby, obstetric complications, and by 1mproving marital and family relations. The introduction of this preventative approach during the preparenthood perlod is further beneficial since couples are more open to suggestions during this time before they establish their family patterns and as their marital committment is becoming a lasting bond.

Part of this study includes the design of a model Preparenthood Consultation Program whlch incorporates the suggestions and recommendations of researchers who have studied the effects of this period on the individual members, the marital couple and the family unit. This model program is based on the premise that the earlier constructive and caring contact is made on a personal basis, the more receptive the recelvers and the more effective the contact will be in assisting familles to learn how to constructively cope with change. 
REVIEW OF THE IIITERATURE

Birth, especially that of the first child, is one of the many crucial events in modern society. It is fraught with uncertainty and luck is frequently thought to play a part in the outcome. (53) W1despread Phenomenon of Maternal Anxiety

The crisis character and critical nature of pregnancy and chlldbirth in a female's life have long been recognized In the psychiatric 11terature. White (67), in 1957; writes about maternal mental 1llnesses assoclated with chlldbearing. Chertok (11), in 1959, speaks of pregnancy as a progressively developing crisis with labour and delivery as its peak. Shainess describes this period as "a crucible tempering the self and resulting in its expansion", if all joes well, or "leaving the self damaged" if all does not go well during the course of pregnancy, labour, delivery and early motherhood.

Beferring to this "crisis period", Stichler, Bowden and Reimer (61) write:

Changes--physlological, enotidnal, and soe lal-occur so rapläly that one can barely grasp their meaning or begin to cope. Because the related experlences, behaviors, and required coping mechanisms are unfamillar, interpretation of them may be inaccurate or invalid. Confusion, insecurity, fear and uneasiness may result.

Haire (30) writes about the cultural warping of the chlldbirth experience in this country. Adamsons 1dentifles this cultural warpins when he states: 
In the U.S., unlike Great Britain and other countries in Europe, the news media often project pregnancy as an event w1th many hazards that are overcome only through careful supervision by highly skilled professionals. In other cultures, pregnancy is treated in a more matter-of-fact way.

Margaret Mead, in much of her I1terature, agrees that other cultures treat the events of pregnancy, labour, delivery, and parenthood more naturally, as fundamental and indispensable aspects of life that are in no way to be feared

Because of this emphasis on obstetric hazards or pathology, much money is spent in the U.S. On increasing technological specialization and equipment for the natural event of childbirth. Governor Brown recently sald in an Interview for East West Journal, February 1980:

We spend an enormous amount of money toward specializations, and the paradox is that with the highly complicated health care intervention spending in San Francisco, just a few miles away in East Oakland we have one of the highest infant mortality rates in the United states.

The facts are that despite the enormous amount of money spent in this country on specialized equipment for use in childbirth-related procedures, the United States continues to have one of the highest infant mortality rates amons developed countries in the world (3). Whereas oultures which have no specialized procedures for what they consider a natural process, have low incldence of infant mortality (3).

Many authors feel that much of the anxiety in relation to pregnancy felt by women in our culture is a trained and soclally reinforced response-- -9 response learned as the 
result of prevalling 1gnorance of the events of pregnancy, labour, delivery and parenthood $(1,9,44,61)$. Regardless of their theoretical framework, most who have studied pregnancy in the U.S. agree that women experience an increase in anxiety and tension during this time.

Yamamoto and Kinney (70), in 1976, wrote about stress and the ablilty to cope with anxiety as belng particularly important in infiuencing the health of the pregnant woman and the child she bears. Ferreira (26), 1969; Joffee (35), 1969; Richardson and Guttmacher (52), 1967, offer excellent Iiterature reviews of studies that have been concerned with the problems of maternal stress and anxiety during pregnancy.

Obstetr1c Complications Caused By Maternal Anxiety

An accumulating body of evidence demonstrates that maternal anxiety is assoclated with complications in pregnancy and childbirth, and that varlous kinds of maternal emotional reactions can influence the fetal environment, the fetus, and its subsequent behav10r. Several invest1gators have hypothesized that anxlety, or the lack of 1t, is the key factor in pregnancy and have confirmed their hypotheses by means of hospltal recoris, case histories, questionnaires, interviews, cIinical observations, projective techniques, and standardized tests $(1,4,9,11,13,16,17$, $18,19,23,39,64,72)$. The most widely used scale in studies of this kind has been the Manifest Anxiety Scale (TMAS). High scores on the TMAS have been correlated with 
abnormal deliveries; Ions total labour tire; low mean birth welghts; obstetric complications; large amounts of analgesia required during childbirth; masital conflict and 1rritability with husband and children; greater dissatisfaction with the motherhood role in terms of hostility, control, and rejection of homemaking; more negative childrearing attitudes; and more rejection of pregnancy and fear of harming the baby $(16,17,18 ;$. One speciflc study found that chlldren of highly anxious mothers had statistically signiflcant lower development quotients in both mental and motor areas (19).

Another study found that high levels of stress, or anxiety, caused sympathetic nervous system hyperactivity, fetal asphyxia, cogenital anomalles, stillbirths, neonatal deaths, premature infants with hyaline membrane disease and low birth welght as well as maternal obstetrics compl1cations. Increased maternal blood pressure, decreased uterine blood flow, reduced heart rate and abruptio placenta were also reported as belng caused by maternal anxiety (4).

Erickson (23) found significant differences between multigravidas (women carrying a child subsequent to their first child) with and without childbirth complications on flve of the nine scales of the Pregnancy Research Questionnaire. Multigravidas with complications had higher mean scores on Fear for Self, Fears for Baby, Irritab1lity and Tension, Depression and Withdrawal, and Lack of Health 
During Pregnancy.

Davids, DeVault and Talmadge (16) observed that women with childbirth complications obtained significantly higher manifest anxlety scores during pregnancy than women who later had normal births. Zuckerman, Nurnberger, Gardiner, Van deveer, Barrett, and Den Breelfen (72) reported that "anxlety during pregnancy was significantly correlated with amount of anaigesia used during labor".

The Effectiveness of Prenatal Education In Reducing Maternal Anxiety

The hypothesis that increased anxiety increases pain perception during labour was flrst advanced in Europe and subsequently led to efforts to reduce the anxlety which were, of course, preparation for childbirth. Preparing couples for chlldbirth in Europe et that time consisted of education as well as training in a varlety of techniques such as breathing, posture and relaxation to be used during labour. These techniques are still taught today.

The purpose of the education is to reduce the overall level of fear regarding childbirth by providing accurate knowledge of the process. The purpose of the specific techniques is to give the wonan a method of coping with the labor contractions, thereby, reducing anxiety, which results in less pain. (11)

Ascher (4) recomnends, more programs of prepared childbirth education and parent education which will reach all segments of the population since, in her opinion, this type of consultation greatly reduces anxiety levels during pregnancy.

Women in our culture seek to obtain val1d information 
regarding pregnancy, chlldbirth and parenting. Typically, obstetricians continue to emphasize the physlological evaluation of the pregnant woman. They give litile, if any, attention to the developmental and emotional aspects of prenatal events, the behaviors of pregnancy or how the couple is interpreting and coping with the experience despite the evidence that pregnancy can produce a great deal of stress and obstetric complications.

Effectiveness of Prenatal Education In Reducing Obstetric complications

Halstead and Fredrickson found that mothers from lower echejons of soclety, who traditionally have a higher incidence of obstetric problems, maj significantly alter the risk factors involved in pregnancy by participating in a structured prenatal education program. "The prenatal education was a greater than expected influence in reducing the risk factor" state Halstead and Fredrickson (31).

At the present time the only large scale program which attempts to reduce maternal anxiety in this country is the natural chlldbirth program which is now ava1lable in most of the major c1ties in the United States. In contrast to traditional obstetrics which focuses on physiological evaluation of pregnant women, these prograns focus on an explanation of the physiology of pregnancy, labour and birth; education and preparation for actively assisting their chlld's birth; and some disclission of the father's plight and role in the prenatal perlod, the birth experience and the early postpartum period. 
Buxton (11), Chertok (14) and Tanzer (64) present good reviews of the theory, history and development of the natural childbirth programs ava1lable.

The courses were offered to couples who would attend the classes together along with other couples. They learned about labour and delivery, medication and anesthesia, anatomy and physlology, concentration and relaxation, breathing awareness, muscular exercises, hyglene, fetal development, postpartum maternal care, and care of the newborn infant. (6)

The Bradley childbirth education course stresses the Importance of chlldbirth preparation stating, "Knowledge builds a woman's confldence in her abllity to work with her body to glve birth safely and naturally." (9) Willmuth, Weaver and Borenstein state, "The role of the mother as an active participant in labor and delivery--no matter what the physicians practices may be---1s generally appreciated as important to a good outcome." (69)

Klusman, in his article "Reduction of Pain in Childbirth by Alleviation of Anxiety During Pregnancy", reports his study of 42 primaparas (mothers carrying their first child) in the third trimester of pregnancy.

Measures of fear and anxiety were taken before and after courses in childbirth education and ch1ldcare. 28 mothers attended Childbirth Education Association classes; 14 of the mothers took Red Cross prenatal classes. Trial analys is of var1ance indicated that both instructions signif1cantly reduced two of three pregnoncy related anxieties, namely, Fears for Baby and Irritability and Tension. (39)

The Childbirth Education Association course reduced general anxiety levels as measured by the IPAT Anxiety 
Scale. Anxiety level was found to exert a significant effect on self-ratings of pain during the transition stage of labour. Pain perception is heightened by high anxlety. It was concluded that childbirth education can reduce fear and anxiety and, thus, also, pain perception. A further conclusion stated was, "Psychological stress and maternal att1tudes during pregnancy have keen found to effect the outcome of pregnancy, labor, and delivery." (39)

Klusman concluded, in 1975, "fear and anxlety may be alleviated in pregnant women by means of some kind of group instruction on childbirth or childcare" (39) after his tests proved that pregnancy-related fears are effectivelg reduced by instruction. This researcher explains,

even primarily informational instruction and the concomitant support that the new mothers receive from the instructor and from the other group members can exert a positive influence on women's attitudes toward pregnancy and childbirth. (39).

Buxton (11), Chertok (13) and other researchers have found that pain is reduced by chlldbirth preparation and that preparation increases self control. A review of the I1terature found numerous references stating that women who are able to (meaning not drugged) and allowed the opportunity of actively participating in childbirth have more fulflling birth experlences than those who rely on physiclans and drugs. $(9,11,13,16,20,31,39,69,72)$

Willmuth, Weaver and Borenstein's research discovered, the technological, solentific approach of today's medicine often fosters the patient's sense of powerlessness. Consequently, there seems to be a 
growing awareness among health cere professionals of the importance of enhancing the patient's sense of control and patient education is considered a necessary part of every diagnostic work up and therapeutic intervention. (69)

Ascher is confident that "dedranatizing pregnancy and birth could result in the elimination of much anxiety"; she continues, "the environment surrounding the delivery process also needs to be dedramatized". (4)-She approves of home deliveries for low risk or normal childbearing families (which is $97 \%$ of the pregnancles in this country, as $97 \%$ are uncomplicated, low risk pregnancies) (3) "as many European nations do". Ascher stresses that "hospitals must consider alternatives to prevent dissatisfaction among patients and the anxiety of the mothers". (4) She strongly recommends, "intervention measures to reduce anxiety, Including chlldbirth education, must be made available". Ascher concludes her recommendation, "To do less is to provide less than optimum care." (4)

The emotional and interpersonal aspects of a marital relationship may be part of a spiral of alterations in behavior affecting the mother, the developing fetus, the birth experience and the motherfather-child triad during the early days and years of development. (33)

Whether the mother's self is enriched or diminished during the preparenthood period is important even beyond the mental well-being of each new mother; for ongoing relationships with her husband and previous chlldren and her developing relationship with her new infant ars also affected positively or negatively by her pregnancy and 
chlldbirth experience.

In the first three months of pregnancy terrific emotional and physiological ad justments have to be made by the pregnant woman. She is becoming a different sort of person both in terms of her physical self (she may be very tired, suffering from nausea and bouts of vomiting) and in terms of her feelings about her self and her body. She may not want intercourse and may view it with distaste. In the last three months she can be weary with the welght of her burden, unable to get long periods of sleep because of what feels like the drumming of football boots inside, or because of heartburn, and she is impatient for the birth. (71)

Women during this perlod also worry about being unattractive or that their husband's will be unfalthful. Everyone in her family is affected by her condition and if no adequate communication is established between her and her partner, her anxiety will be increased because of these unsettling reelings.

Interfamilial Relationships

The pregnancy period is a time of anxiety for both mother and father-to-be, in our culture, as they encounter new demands of both physical and emotional natures. Stichler, Bowden and Relmer conslder pregnancy a shared emotional experlence after their research found that "fathers respond quite dramatically to their mate's emotional changes and demands, her physiological changes, and her altered body 1mage". (61) These researchers state that fathers exper1ence their own inward changes as well.

Cavenar and Butts refer to emotionel 1Ilnesses in men related to their wives' pregnancles. The1r investigation 
tionship with hde child, unconsclous envy of the woman's reproductive capacities and latent homosexual conflicts in men as reasons'forinegat lve readtions to therrintros' pregnancles. (12) In Freeman's account of 6 patients, the argues that pregnancy in women brings on mental 11lness in men. Hartman investigated 91 expectant fathers in an Amerlcan court psychiatric clinic and showed that sexually devlant reactions were more frequent than for a comparable group of non-expectant fathers. Sexual deviation was interpreted as a "regressive, 1mmature adjustment to the anxlety of fatherhood". (12)

Expectant fathers in an American m1litary camp had an extensive list of symptoms including:

depression, accident proneness, overeating, gastrointestinal symptoms, the development of new athletic interests and hobbies (possibly extramarital ones) and a desire by some to be on the move changing camps. (67)

Rlchman, Goldthorp and Simmons suggest that "Modern man has typically cocooned himself from the crisis of fathorhood and the uncertainties of birth." (53) Author1ties write of husbands interpreting the1r wives' mood changes during pregnancy, as indicative of their (the husband's) Inadequacy or of a multitude of traits which threaten his self-image.

Evidence of Paternal Anxiety

Researchers have found that expectant fathers and newborn fathers experlence a change in Iifestyle; a loss of 1dentity; loss of power and loss of intimacy. $(8,25,36$, 
$40,53,58,67$ ) They must struggle to assume the household tasks previously performed by the wife and often experience Inancial problems. Fasteau (25) found, in 1974, that men depend on and expect from their fives a full-fledged 11 fe support system which is pulled away from them during preparenthood. Yet seldom has elther partner had much useful preparation for parenthood changes other than the fact that they were both chlldren once.

It becomes evident, in light of the previous findings, that males in our society experience great identity crisis. during the events of pregnancy and early parenthood. LeMasters writes, "The American father is poorly prepared for his fathering role." (40) Th1s is understandable since father is usually excluded from the events of pregnancy and, thus, allen to the knowledgeable fathering role In the early postpartum period. Typically, the father is excluded from the entire pregnancy and binth experience.

B1Iler and Meredith see a crisls confronting fatherhood and define it in the opening chapter of Father Power: "The principle danger to fatherhood today and to the Amer1can family for that matter, is that fathers do not have the vital sense of father power they have had in the past." Psyohologist Dr. Lee Salk feels that soclety has largely deprived fathers and their chlldren the rewards of early fatherhood. "Amerlcans tend to think of fathers as belng background flgures who enter the picture only when the child is older and needs to be punished or launched into some 
manly pursuit." (58)

Terry Jones, co-founder of Portland's Prepared Ch1ldb1rth Association writes: "Pregnancy is a transition crisis and a man is often dealing with something he has little concept of." (36) For example, he explains that when he asks expectant fathers what they envision their babies will look 11ke, most of them describe an elght year old! Jones says, "Pregnant men have been 1gnored for too long." (36) He feels little is being done regarding psychological adjustment in preparing for the birth of the baby, especially for the male. Jones has found that men sometimes resent the attention their wives recelve from friends and relatives and they feel left out. Few obstetricians meet w1th the father at all during the prenatal perlod and many do not know to whom to announce the baby's arrival. Preparenthood Education and Counseling Needed

Stichler, Bowden and Relmer found, with thelr research, "couples usually recelve little or no support during the crisis of coping with prenatal problems and what support they do recelve is inadequate". (61) Friendly advice which emphasizes the positive aspects of pregnancy and delivery without due attention to the facts, the inconveniences and forced compromises involved,

give prospective parents very little preparation for dealing with all of the realities of pregnancy and parenthood. It also causes the couple to feel guilty about any negative feelings that they may have regarding the experience. (61)

These authors affirm that mutual support is necessary 
based on the fact that at times the pregnant woman has mood changes over which she has little or no control due to the rapidly changing hormone levels, Communication with understanding becomes more difficult bscause of these unpredictable and often intensely exaggerated mood changes. "The pregnant couple must develop a new style of communicating with each other and of interpreting the other's true message and needs." (61)

Stress In Marital Relations During Preparenthood

"One out of every two marriages today ends in divorce", says Dr. Fran Page, family therapist at Tualatin Valley Mental Health clinic. "Frequently these divorces occur after the arrival of a new baby in the family", Dr. Page says. "Couples who need help most don't ask for 1t when in the midst of great family turmo1l", says the Eroup educator for Parent Effectiveness Training in Portland.

Hott writes about the phenomenon of the husband "taking leave of the family" during pregnancy, particularly toward the latter months and immediately after the birth.

During this period the father's must accept their wives ever-changing shape and often accept abstention from sexual intercourse. They must accept more responsibility, also... A facetious restating of the marriage vows might include until birth do us part!(34)

She emphasizes,

pregnancy is a time of great stress for expectant parents; men must be offered opportunities to discuss their problems and feelings; and the importance of observing the couple in their nome. (34) 
One of the first unique experiences of the pregnant male 18 a sense of separateness from the woman and what she is experlencing. However, his feelings, thoughts and experlences are largely 1gnored which result in a deepening of this allenated feeling. At different phases of pregnancy women can enter into periods of relative frigidity. This sometimes carries over to 2 months postpartum and through the breastfeeding period, which is sometimes recommended to last at least 7 months. Men may feel not only separated but inadequate when their usual sexual expression is cut off. Some men become jealous of the coming baby who is getting so much attention and interfering with the couple's normal iffe together even before it is born.

It is not difficult to imagine the full impact of preparenthood on fathers since they have been banned for years from the delivery room. For too long fathers have been 1solated from the experlence of their children's blrths. Men have been allenated and, in actuality, forced out of experiencing one of the most precious moments of family l1fe. It is no wonder that, as Benson states, "The American father is almost invisible, perhaps even at home." (7) In The Naked Nomads (27) the author says that the marriage bond is essential for the male to provide selfesteem and meaning in $h 1 s$ IIfe; that the support and protection of the fenale are the most definitive masculine functions in our soclety.

Robert Mendeisohn, author of Confessions of a Medical 
Heretic and a medical doctor, stated in a recent interview (Apr1l 1980, East West Journal):

Doctors have resisted husbands being in the delivery room because unconsclously they don't want that competition from the husband. Otherwise they lose their hold on the mother.

He continues,

I have seen very few expressions which equal that of $a$ woman who has just had a baby and her feet are st1ll up in stirrups and a doctor is sewing up her eplslotomy and she turns to $\mathrm{h} / \mathrm{m}$ and says, oh, thank you, doctor', or 'Oh, doctor, I love you'.

Mendelsohn's emphasis of this expression is dynamic when one understands that the birth process is accomplished, almost w1thout exception, by the woman, not the doctor, and rarely, if ever, is an epislotomy necessary. (3) Mendelsohn continues,

The expression that a woman at that moment gives her male doctor often rivals or exceeds that which she shows for her own husband. That sets the stage. At the same time, of course, the male doctor by intervening has caused a certain amount of pathology which guarantees that the woman w11l need some kind of medical care for the rest of her l1fe.

Maternal-Infant Bonding Is Important

The nature of the bond, or slose emotional tie, that a mother forms w1th her baby has become the focus of extenslve studies, which have 1mportant practical implications for the care that hospltals provide to fanllies during and after chlldbirth. Ashley Montagu writes:

The moment it is born, the cord is cut, the child is exhibited to its mother, and then it is taken away by a nurse to a babyroom calied the nursery, so called presumeably because one thing that is not done in $1 t$ is the nursing of the baby. Here it is welghed, measured, 1ts physical and any other traits recorded, a number is put around its wrist, and it 
is then put in a crib to howl away to its heart's discontent. The two people who need each other at this time, more than they will at any other in their lives, are separated from one another, prevented

from continuing the development of a symbiotic relationship which is so critically necessary for the further development of both of them. (45)

Margaret Mead felt deeply about the routine interruption of this "anclent tie of early intimacy between $a$ mother and her baby" (44). In her book, Fam11y, Mead emphasizes,

Wherever it has been customary for a mother to suckle her own infant, the child has been assured a continuing relationship with one numan being who has satisfied its hunger and given it $a$ sense of safety and trust... The way modern civilization has typically interrupted this ancient tie of early intimacy between a mother and her baby forces too intense a weaning at the moment of the piysical birth experience from which an emotion of distance and of allenation results which may dwell in the individuals throughout thelr iffetime. (44)

Klaus and Kennell found:

the first minutes and hours of life may be espec1ally, perhaps critically, influential for the inltiation of the maternal bond, triggering a sequence of nurturing responses that may have long-lasting effects on the mother-child relationsh1p. (37)

Other researchers have recently begun to examine the nature of the bond that a father forms with h1s baby. $(28,33,46,47)$

Klaus and Kennell (37) and Rlchards (51) report, based on their separate research studies of human mothers, that the mother's behavior patterns toward her new infant become set at the time of birth and the days 1mmedlately following. Separation leads to the emotional feeling of distance between newborn and mother and father. Because early fatherbaby interactions may be basic to the development of a strong 
father-child relationship later in $11 \mathrm{fe}$, support for the father's role in chlldbearing and after birth in the hospital is essential. Pollinger, in a study of 60 wornen, found that "the obstetrically-controlled system of childbirth management is higily inconsistent with the strong values placed on family cohesiveness".

Bonding Father With Mother And Infant

Due to consumer demand, some hospltals now allow fathers to witness the birth of their infants. Richman, Goldthorp and Simmons interviewed 150 fathers, 100 of whom were allowed to be present but not active during the birth of their children and $=0$ of the fathers were present only during the labour. All agreed that pregnancy caused behavioral changes in their wives and that certain aspects of their relationships were altered. Some men in this study described how their wives were "taken away from them to deliver their bables" (53). These researchers describe common treatment of the attending father in the delivery room saying, "he has to abandon $h 1 s$ traditional role as protector and provider and be more like a frozen rabbit" (53). $15 \%$ of the fathers studied sald that "the main thing they disliked about the birth was their impotence" (53) in not being able to help the1r wives.

The authors felt these men struggled to make sense of pregnancy and "In trying to make sense of pregnancy, the most convenient and intelifible way is to classify it as an 11lness" (53). They conclude, "Fathers can be sald to be 
allenated from the process of reproduction." (53) Recommended, based on their study, was an earnest effort to inform and include the husband and father who wants to attend the birth of his child. 93\% of the fathers represented in this study welcomed the opportunity and stated they would want to be present at their next child.'s birth. Approximately half sald they enjoyed,

hearing the baby's first cry and seeing the baby's head appear. Other comments were about the wonder of nature and sentimentality generally attributed to females. A third were pleased to have supported their wives by their presence alone. (53)

The presence of the prepared father during childbirth has been linked with increased feelings of paternal involvement with both mother and baby, and it can have a positive affect on how the mother percelves pain, can decrease her use of medication, and can make the birth experlence much more rewarding for her. (42)

\section{Childbirti Education Classes}

Prenatal education classes are extremely 1mportant in reducing maternal and paternal anxiety levels during pregnancy and childbirth. As well as providing information about pregnancy and childbirth, these classes teach women the concept that they may have some measure of control in helping their children to be born. The classes offer information regarding how women may best assist del1very. Some methods of prenatal education encourage the father's active participation during labour and delivery, supporting the father's role as husband, coach and father. Most methods emphasize good nutrition; the avoldance of drugs throughout preparenthood; relaxation and breath1ng; 1mmediate and con- 
tinuous contact with the new baby; and breastfeeding beginning at birth.

Members of both La Leche League International and International Childbirth Education Association have benefited tremendously from the positive attitudes the groups generate. Along with their many helprul practical hints, these attitudes tend to become imprinted on the mind so that constructive parental reactions are almost automatic after birth. Classes also give expectant parents a very strong feeling of competence in the whole affatr, which many believe to be one of the most important ingredients for $a$ successful, happy chlldbirth experlence! Togetherness and group empathy are especlally 1mportant when a woman---or a man---may be feeling a mult1tude of fears and doubts about the impending exper1ence, especially if it is a first-time venture. (10)

Fathers Present At Delivery

Bradley views birth as an important part of the couple's love relationship. He emphasizes the intimate nature of labour and birth as an act of love. Being an act of love, Bradley feels that giving birth should be shared with the person the mother loves. His research has found that "A laboring woman gives birth more calmly and conf1dently, needing less or no medication in labor when she has a loving coach beside her to support her." (9) With the father as coach, optimal bonding is allowed to occur between mother and father, father and child and mother and infant at the time of birtin.

Henneborn and Cogan support with their investigation of 49 births the importance of the father's attendance during the labour and birth of his chlid. 38 of the fathers attended the birth as well as the labour. 11 husbands attended only through the flrst stage of labour. All 
couples had LaMaze or psychoprophylactic method of ch1ldbirth education classes and the husbands were encouraged to participate as labour coach throughout labour and de:-:-

\section{Iugery.}

Those wives whose husbands attended both the labour and birth reported less pain and had significantly lower probability of receiving medication during labour and birth. Husbands and wives who a.t tended labour and birth together reported more positive feelings about the total birth experience. (33)

Henneborn and Cogan concluded, based on their reserrch findings, "The father's attendance at the birth of his child may have long-reaching effects upon the ch1ld." (33)

In a study of 111 coupies, 92 did not attend classes and 19 were prepared childb1rth couples, $(9$ couples trained according to the Chlldbirth Education Association's classes, 5 couples educated by the LaMaze nethod, 4 couples recelving Kltzinger's Psychosexual Method education and 1 couple trained in hypnosis). The format of all of these classes included general aspects of labour and deliverj, postpartum care, relaxation exercises and breathing. $46 \%$ of the couples took the prepared cillldbirth classes primarily so that the father or husband could be with the wife during the labour and birth. The second most prevalent reason for taking the prepared chlldbirth classes was because the couples wanted information concerning the labour and deI1very experlence. (68) Remarkably similar findings, regarding wanting the father with her during labour and the delivery and wanting more information about labour and de11very, are evidenced in a survey of prepared childbirth 
couples in Rhode Island. (66)

Hospitals which now allow the father's presence in the delivery room require that the couple attend preparation classes. Whitley's study (68) points out the fact that prepared chllabirth classes are much more informative for couples than the conventional hospital prenatal classes. The conventional classes discuss hospltal procedure rather than focusing on patient participation and the actual mechanics of the labour and delivery process. This must be considered in reviewing the literature which sometimes equates the two. In this study only prepared childbirth classes are discussed unless specified otherwise.

EISherif, McGrath and Smyrski testify to the recent demands of parents to be togetiner during the labour and birth of their chlldren. They describe the father, saying, "H1s physical presence is now allowed in some labor and delivery units, but essentially he continues to be the forgotten man." (21) They stress to the hospital childbirth team the necessity of including father as an integral part of the laboring couple, "as his presence not only supports the woman in labor but he also may act as a coach encouraging the mother of his chtld". (21)

All registered nurses themselves, ElSher1f, McGrath and Smyrskl advise that the father in labour and delivery should be treated as "an assistant assuming his now role as parent rather than treating him as a casual observer" (21). They continue, 
His presence at the delivery has the opportunity of facilitating the labor and delivery process, enhancing his self-esteem, improving the couple's relationship, and helghtening parent-infant bonding. (21) Effectiveness of Childbirth Education

Doering and Entwisle interviewed 269 new mothers to determine effects of preparation for labour and delivery on their perceptions of childbirth and their bables. They found that "the more preparation a woman hod, the more aware she was at delivery and that awareness was strongly assoclated with positive reactions to the birth and the baby" (20). These findings are interpreted in terms of theory on coping with stress.

The sample population consisted of 269 women who were marrled and living with the Ir husbands. All had given birth to a living, healthy child within the previous nine weeks. The subjects were located in two different ways. Most of the trained subjects were contacted through local chlldbirth preparation classes, w1th the cooperation of certifled trainers in each area. Precautions were taken, so that the trainers did not refer only probable successes. The interviewer recelved a list of all women registered in each class long before they delivered. The subjects were chosen randouly from these lists and then contacted after they delivered.

All of the untrained subjects and $z$ few trained ones were located by referral from other subjects. The acquaintance was most frequently a distant one. This provided a 
w1de varlety of doctors and hospitals and, thus, a diversity of childbirth experiences. 116 doctors and 38 different hospitals are represented in Doering and Entwisle's sample. Nine births occurred at home and were planned to be home deliverles. Three home deliverles were unplanned. The interviews were conducted in each new mother's home and lasted one to two hours. The women were told that research was being done on the psychological or emotional aspects of the chlldbirth experience. AlI subjects were contacted between 1965 and 1970 .

Doering and Entwisle found:

Preparation of even a minimal sort thus appears to enable women to cope more successfully with the childbirth experience and to be more aware at the actual birth. Women who were fully aware have a more positive attitude toward childbirth and postpartum and react more positively toward their bables in their initial encounter. Women who have more positive first reactions toward the ir newborns, continue to have a closer mother-child relationship in the immediate postpartum period. (20)

Recent research indicates that there is less chance of minimal brain damage and other complications of labour, b1rth and early I1fe when the normal process of birth is allowed. $(4,9,20)$ Bradley style advocates report that "when the natural process of b1rth is respected, family ties form more strongly and quickly". (9)

Besearch findings show the importance of adequate preparation $(9,20,21,25,36,40)$, sat1sfying relationships $(16,17,18,34,36,37,42,44,45,49,51,58,61,67)$, communication and emotional well-bolng during the prenatal period $(9,10$, 
$21,27,36,53,61)$; the 1mportance of the mother's readiness for the pregnancy and her level of preparation and knowledge regarding labour, delivery, and mothering $(9,20,21$, $33,49,61,70)$. The research supports prepared chlldbirth and prepared parenthood as being very useful in reducing maternal and paternal anxiety and obstetric complications. Counseling During Preparenthood

Preparation for childbirth and parenthood would be even more effective if it included marital and family counseling in addition to pregnancy and childbirth education. Ascher stresses the 1mportance of alleviating maternal anxiety during pregnancy saying, "sensitivity to the mother's individual needs is of paramount importance" (4) and suggesting, based on her research, that "information, explanations and reassurance from someone who is both knowledgeable of the subject and interested helps greatly" (4).

Pregnant women and their partners want to turn to someone for assistance with the expression of feelings of Insecurity and fear related to pregnancy and early parenthood. Usually they cannot relate with their doctors for, as one registered nurse writes, "women cannot be given adequate time for such sharing at their appointment with the physiclan" (66) attending them. "Nurses may find 1t hard to reconcile the best interests of the parents with those of the hospltal and the physicians." (66) Watson recommends "an outside consultant" (66) for educating parents. 
Watson, after researching the effectiveness of childbirth preparation, (her research focused on the records of 105 couples) states,

In view of the finding of this investigation it is recommended that: An effort be made to reach the majority of expecting parents; and publicity be directed to reach a maximum number of expectant parents early in their pregnancies. (66)

Rubin writes, "Maternity nursing stops too soon" (56) emphasizing the importance of knowledgeable attention in the postpartum period. Stranik and Hozberg state in their article, "Transition into Parenthood" written in 1979,

Few support groups are avallable for parents in the first month to six weeks postpartum, yet this is the time when adjustment to parenthood is at its peak...the traditional gap between obstetrics and pediatrics staffs leaves famliles without an active support system between hospital discharge and the first routine baby visit to the pediatrician 5 to 6 weeks later. (62)

Several authors emphosize the need for emotionsl assistance during this transition period from birth through the sixth week of the infant's I1fe. $(2,54,56,61,6 ?, 63,66)$ Rising writes of the importance of identifying and helping to integrate fathers, mothers and infants who find relating with each other in the after birth period difficult. "Even well-integrated families must make extreme adjustments the first two weeks." (54) She stresses that intervention has the opportunity of belns impactful during the immediate postpartum period sayins,

There is a certain openness about this fourth stage perlod that may never occur again. All efforts should be made to allow the father, the mother and the infant to share this momentous time together. (54) 
Another researcher urges, "Certainly any method which takes Into consideration the psychosocial needs of the couple is bener101al." (1)

Dr. Sugarman's work concludes:

1- There is a clear need for more attention to be devoted to good prenatal nutrition and physical care, and to emotional and factual preparation for childbirth and parenting. 2- Highly technological or artificial obstetrical jntervention must be reserved in the future for nigh-risk or complicated pregnancies and births. The trend toward greater and greater management and control of birth and the birthing woman must be reversed to allow the natural birth processes to proceed to their emotionally and physically healthiest conclusion. In this regard, the greater use of family pract1tioners, midwives, and nurse-practitioners in mony areas of the world and here in this country have proven more economical and diminished the overuse of technology and pathology-orlented care by overqualified specialists. (63)

Arms (3) agrees with this second conclusion as does Haire

(30) and Ward (65).

3- More attention to and support for the motherinfant interactional relationship in the immediate postpartum period is clearly indicated. Roomingin, family-centered care of the mother and infant. together, supportive intervention in complicated situations, encouragement and education for breastfeeding can improve the quality of attachment dramatically. 4- For normal mothers and newborns, early discharge from the artificial environment of the maternity hospital, along with improved early follow-up care at home is a way of promoting attachment without abandoning the mother-infant pair for those difficult first weeks of 11 fe. 5In the case of complicated births or 111 newborns, where resionalized maternity newborn care will play a large role, more attention must be pald to the affected family's needs for psychosocial support and avoldance of mother-infant separation. 6Finally--and tinis may be a highly controversial 1ssue---pirents-to-be need to have avallable to them a spectrum of birth ilternatives. Many physiclans feel that only hospital birth is safe for mother and Infant, and are reluctant to provide 
service in other settings, such as out-of-hospltal maternity centers or at home. The evidence from selected populations in parts of the United States and in other countries does not support this preference. But, more importantiy, the responsibility for the new Iife lies with the parents, and the setting for birth should be their active decision to make with complete information, preparation, and understanding of the responsibilities they are assuming. (63)

\section{Limitations of Childbirth Education}

Childbirth education is considered by many to help in reducing the incidence of maternal fear during labour and blrth. These classes, at best, enable father to feel less alienated from the events of childbirth and pregnancy by including him in the group discussions. However, childbirth education programs of ten do not address themselves to preparing the couple to meet the demonds of parenthood. Childbirth education also may not adequately satisfy the emotional needs of elther father or mother-to-be; allow for discussion of family or marital problems during pregnancy nor prepere couples for problems commonly assoclated with early parenthood.

The childbirth education programs usually occur during the last 6 to 8 weeks of pregnsncy and sre Iimited by their short duration and brief intervention with ench group of couple's. Most programs offer no follow-up during the early postpartum period when the elation of birth is over and the reality of new IIfe begins. Usuelly childbirth education programs focus on the last months of pregnancy, labour and birth prepartion. Interpersonal commu- 
nication and copine mechanisms which are gained through the childbirth education programs are individually and indirectly obtained. Importance of Emotionel Preparation For Childbirth

Authorities now stress the importance of the systems approach to intervention with people at the psychosocial and soclocultural levels. "By falling to stend to the person and soclocultural levels, where disease is shaped into the human experience of 1IIness, contemporsy medicine undermines its own effectiveness," $(24,38)$ The neglect of adequate individual attention during the crisis preparenthood period for some mothers and fathers and their existing families may contribute to various social problems. $(15,32$, $47,48)$

Kopfer's research on animal behavior reports:

If the young are not seen immediately after delivery the mother does not desire to take care of them. She will reject them, even if she is heavy with milk. She has lost the strength of instinctive maternal responses that a properly imprinted animal mother is believed to foster automatic sily. (10)

Dr. Marshall Klaus' study of human mothers found that the mothers behavior patterns toward her new infant become set at the time of birth and in the days immediately following. This period seems to be extremely important for the future of the Individuals and may also be important to the wellbeing of the family unit.

After conducting prenatal interviews and behavior observation sessions with 46 families in which the woman 
was pregnant and again interviewing the familles and observing them at 7 days, 1 month, 2 months and 6 months after the oh1ld was born, Peterson and Mehl found "The most signiflcant varlable predicting the varlance of maternal attachment was the length of separation of mother and infant: less separation was assoclated with greater attachment." (47) In addition, these authors found prenatal attitudes and expectations 1mportant. They "envision the mothers experience during labor and delivery as a cruclal trensition point in the development of maternal attachment---a period. of creative stress or crisis" (47). They emphasize that "The mother's assoclations with labor and delivery will affect the b1rth process" (47) and subsequent maternalinfant relations.

During the birth process, the mother is tremendously vulnerable; she is opening up both physically and mentally. Separation from her infant following delivery may act as a powerful punishment for that kind of behavior but the presence of the baby may be a powerful reward. (47)

Negative Birth Experiences Related To Child Abuse

Peterson and Mehl comment on the beneficlal effects of a positive birth experience on maternal self-esteem. They warn,

A negative birth experience in which fear and pain and discomfort predominate may have far-reaching consequences. Fear and pain breed resentment and hostility toward the object associated w1th the fear, pain and discomfort. (47)

They found that fathers also express hostility toward their infants when the infant's birth was an experience of pain 
and fear for the1r wives. "Such a phenomenon has also been observed in clinical psychiatric practice. This is in sharp contrast to fathers and mothers who percelve birth as a positive emotional experience." (47)

Dr. Milton S. Grossman, pediatrics cha1rman at Mount Sinal Medical Center in Mlain Beach and professor of pediatrics at the University of Miami thecrizes that separation of mother and lnfant brings not only a fallure of the maternal instinct but increased possibility of childbeating. (10) Helfer and Kempe's synthesis stromgly suggests:

The process of bearing and nurturing new Iife is a complex one, influenced powerfully by subtle, interacting factors whose long-range effects are difficult to predict end observe. Ten years ago (In 1958), pediatricians noted that many of the premature infants they labored so hard to save were brought back to the hospital battered, neglected, and abused by their parents. A very high proportion of children who are abused or fallures-tothrive have been premature, born by Cesarean section, or hospitalized for other reasons in the first weeks of $11 f e$. These are extreme and easy to see effects of the fallure of maternal-infant attachment. (32)

Dr. Elizabeth Faust, a practicing psychiatrist in Haverford, Pennsylvania says,

One of the top causes of infant death is violence at the hands of the parents. I feel strongly that the tendency of parents to beat their children has dramatically increased over the same period that there's been a terrific lessening of contact with infants and adults. Infonts are more isolated than they ever were. And people who sre having bables now were subjected to considerable isolation when they were infants in the $1940 \% \mathrm{~s}$ and $1950^{\circ} \mathrm{s}$ when it had already become universally the practice to put infants in hospltal nurseries at birth and keep them totaily isolated. (10)

Helfer and Kempe write: 
If we looked more closely, we might see less obvious effects in apprentiy normal families in which this critical attachment $h: s$ been distorted, diminished, or blunted by routine, unexamined medical and cultural practices. We must begin to take this closer look. We must begin to make profound changes in our attitudes toward birth, the newborn infant, and the family unit. The goal must be to intervene in pregnancy, birth and the early postpartum period only in ways that are examined from the point of view of promoting both physical and emotional well-being of the mother, infant, and family. (3̣2)

Dr. James Prescott, a neuropsychologist w1th the

National Institute of Child Healtr and Human Development says,

If newborn infants received more affection, there would be less violence, crime, arus problems, psychlatric disorders and all the other problems that plague us....A chlld's needs for early touching is as vital as food. It should be held and fondled right away. (48)

The Preventative Role of Soclal Work

Sobel writes:

Contemporary Western medicine is a valuable but incomplete approach to health. It has concentrated on disease and neglected health. It has emphasized Individual medical care and slighted the influence of environment and behavior. It has been preoccupled with physiochemical processes and remained insensitive to psychosocial factors in health and disease... (60)

Soclologist Dorothy Beck and social worker Mary Ann Jones of the Family Service Association of America conducted a four-year study of 3,600 family problem cases across the nation. Approximately 13,000 individuals were 1nvolved. The study indicated that with children second and sex third the leading cause of fanlly conflict in $87 \%$ of the cases was a breakdown in communication. 
Dalley writes about the breakdown in communication

during pregnancy:

Women need to learn to respond to their husbands' reactions to pregnancy in an informed and supportive manner. Men have the right to be excited, scared, ambivalent, and even guilty, and they need opportunity to talk about those feelings. It is important that the woman be able to respond. (15)

Richman, Goldthorp and Simmons state,

The role confusion and upheaval they are exper1encing needs to be explained as normal, expected, and common to the husband-wife relationship during pregnancy. This validation of normality is helpful to the couple, lest they belleve that their relationship is in peril. Pregnancy is a new experlence to most couples, and few couples know what they can expect. If no one helps them to meet their individual emotional needs in face of the stress they are under, the spouses will never be able to be effectively supportive to the other at a time when such support is most needea. (53)

Several authors have discussed men's need for assistance with the fathering role. $(8,12,25,36,40,53,61,68)$ Fasteau describes fathers as "not having learned to value the kinds of rewards inherent in daily child care", in parenting. He feels "fathers tend to be focused on the outcomes rather than enjoying the process" (25).

B1ller and Meredith write of the importance of father's attention to the infant and give suggestions for healthy fathering. Salk addresses himself to the central core of his book which is the well-documented observation that bables who are understimulated do not develop as well as babies with adequate stimulation, saying that fathers can enhance an infant's development very significantly. This fallure to get fathers physically and emotion- 
ally involved in the care of their chlldren from the moment of birth may deprive children of real1zing fully the potential with which they were born.

The father, like the mother, must be adequately prepared during pregnancy for his new role---for the advent of fatherhood when finances, energy, attention and responsibilities concentrate even more demands on the father. "People seek emotional support from a signiflcant other when their anxiety increases." (53)

The trained marital and family social worker who knows how to inspire effective two-way communication in interpersonal conflicts so that no one loses and the family wins; who knows how a person can influence another to be considerate of his needs; and knows a method that w1ll help a person work through his personal problems and find his own solutions would be of valuable assistance to families experlencing preparenthood.

The soclal worker trained to deal effectively with disharmony in sexual relations and educated as to the adjustments that must be integrated and the coping mechanisms useful upon the advent of a new family member would assist the preparenthood couple greatly. When a man needs to express his confusion and other feelings which are normal when transcending into a new role of his manhood---that of father---the social worker could facilitate this expression.

The importance of facilitating marital, individual and family understanding by establishing, reinforcing and 
maintaining open ines of communicition is clear. So, too, is the need for valid information regarding pregnancy, labour, chlldbirth and early parenthood.

The medical profession is not assisting couples in expressing emotional uneasiness and constructively working with feelings of insecurity, fear, jeslousy, guilt, etc. These essential aspects of pregnancy have been neglected despite the evidence that pregnancy can produce obstetric complications if anxiety is not reduced through education and counseling.

Consultation is a major undertaking requiring knowledge, sensitivity and time along with professional interpersonal communication skills. For this reason, no person is more well sulted to take on the task then the social worker educated in pregnancy and early parenthood education and individual, marital and family therapy.

Research On Preventative Approach to Fam1ly Therapy

A number of articles in social casework journals Imply a preventative approach to family therapy. $(5,15,22$, $41,50,55)$ Medical journals and psychlatric journals also conclude by reasoning from their research with pregnant couples that more emphasis must be given to the psychological and psychosocial aspects of pregnancy. $(1,4,12,19,21$, $28,36,46,61,67,72)$

Selig, in an article, "The Myth of the Mult1-Problem Fam1ly", states:

Our current service delivery system, 1tself fragmented, may do more to promote than relleve family 
disintegration, conflict, and personsl anxiety. Continued professional training and tendencies that lead to viewing problems presented by individuals only as individuil problems may result in overlooking opportunities for total famlly approaches to treatment and prevention... We are learning that many systems we have created to deliver services are, in the name of progress and civilization, contributing to the conditions of human distress they were deslgned to alleviate. (59)

Auerswald writes,

The integrated team approach to structuring and providing services to the entire family will increase opportunities and probability of maintaining family integrity, as well as improving the effectiveness of interventions, since family nembers' influence upon one another might beneficially be brought into play. (5)

The "integrated team approach" Auerswald refers to consists of the professionals who are working with a family (obstetrician, social worker, pediatriclon) gathering together to discuss the family's welfare and meeting with the entire family unit as a team.

Rhodes states:

The shift in social work practice from individual to family treatment models of service which emphasize intervention at points of interface between coping efforts and environmental contingencies and the emphasis on preventative approaches are several of the major trends which give impetus to solid1fying $a$ theoretical base for understanding and influencing families. (50)

Erik Erikson 1dentifles different stages of the life cycle as being potential crisis periods to individuals.

He emphasized the importance of intervention upon the advent of these perlods. Two of these phase-specific crisis perlods occur during preparenthood. The first phase of 'Intimacy versus idealization or disillusionment' is one of 
"forming a dyadio relationship which precedes the advent of offspring". (The essential criterion of this stage being that the couple is making an investment in the relationsh1p.)

The tasks involved in this first stage are of a critical nature as they are fundamental aspects of bullding $a$ relationship such as (1) assuming responsibility for oneself in the relationsh1p; (2) negotiating differences and conflict with one another; (3) resolving unrealistic expectations of one's partner; and (4) finding mutually sat1sfying ways to nurture and support one another, it is referred to as being a period of extensive upheaval and conflict. $(40,50)$

Courtship patterns and expectations, the nature of early interactional pacts (usually implicit), the vying for power positions, and the assignment of roles and responsibilities are early indicators of the couple's mutual capacity for intimacy, of their progress in working toward intimacy and of potentially dysfunctional patterns in the achlevement of intimacy. (50)

Each partner's capacity to achieve intimacy as opposed to 1dealization is reflective of the extent to whlch he or she has completed the tasks relevant to his or her own nuclear family. Thus, the mult1generational perspective which resonates throughout the model surfaces meaningfully in this first stege. (50)

Social work intervention during the prenatal period can be effective in establishing marital coping mechanisms for future stress periods of life. During this first stage the shared awareness of mutually felt dissatisfactions, frustrations, and satisfactions can be the foundation for greater openness, understinding and sppreciation of differences. Many couples need assistance with interpersonal 
comnunication skills and feeling ldentification; assistance in locating areas of differing expectations and conflict, exploring potential problems, volcing self-identifled needs and feelings and constructing ways to support each other. The second stage begins with the birth of the first child and ends when the last and yourgest child enters school. It is termed 'replenishment versus turning inward'. The major struggle of this stage enta1ls "the development of nurturing patterns among all family members so that food, In an emotional sense, is avallable to adult suppliers as well as to their helpless offspring". The concept of "refueling the adults", whlch suggests a responsive and caring environment within the fomily unit, is mentioned by Mahler, Pine, Bergman (43), Rhodes (50) and others.

The abllity to succor, to be avallable and responsive to the needs of young children depends on the presence of both inner resources and opportunities within the family environment for refueling the adults. (50)

In the couple's relationship after the first and only Infant is born, refueling is a mutual necessity for both parents and the degree of mestery, by both the mother and the father, in offering this sensitive, understanding encouragement will decide the extent to which this couple cope's with the demands of this vitally impactful transition from a couple to a family. The couple who have succeeded in achieving the intimacy of the first stage of their relationship are obviously in a better position to make the necessary adaptations to a new family nember, who is both 
helpless and demanding, than those couples who have not resolved the intimacy stage successfully.

Preventative Educrtion And Counseling Needed

Rhodes suggests,

Accessibility of parent If education groups which foster sharing of experience as well as information is a change at the institutional level which would provide the nucleus of a social network within and without the nuclear family and expand interface points between family and nonfamily worlds. (50)

There exists no family liason during preparenthood The single adult would also be greatiy assisted by the preparenthood consultation service during this interval because presently the single parent, who is particularly dependent on refueling sources outside the fam1ly, is not provided for by our society.

Blanca Rosenburg, in an article "Planned Short Term Treatment in Developmental Crisis", stresses the importance of "the organization of family life education programs geared to nonclinical populations and located for direct access at critical points" $(55)$.

Many soclal workers $\nabla$ lew the purpose of soclal work to be that of producing growth through increasing competency in coping with the social situation or environment. They feel, as do Russell and Schild "the task of the worker is to engage the cllents to begin to move toward taking control of their situation" (57). Problem-solving and dec1sion-making are facilitated by the rorker but basically resolved through the indivudual's acceptance of respons1- 
bility and control once the source of the crisis is 1dent1fled.

Some parents are in need of preventative services which are most effective when introduced, logically, at the first transition phase of the familial relationship---when encountering the adjustments required for transcending the couple to attain appropriate and healthy family ilfe. There are usualiy no negative responses to consultation and no resentfulness toward treatment to work through before education and counseling can comnence. Pregnant women are of ten elated to find an empathetic and knowledgeable professional person to communicate with and learn from during the prenatal period and through the events of the postpartum.

\section{Conciusion}

In this work documentation has been presented from research studies evidencing (1) that preparenthood, from conception of the infant to six weeks after the infant's birth, is considered a crisis period of stress and anxiety for the mother and father individually, for the marital couple, and for the family system; (2) that the widesprend phenomenon of maternal anxiety causes obstetric complications; (3) that a negative birth experience con result in soclal problems such as child abuse; and (4) the need for a nonclinical consultation program which reaches the majority of expecting parents during the preparenthood period of I1fe. 
In 1966 there was a tremendous growth in the fleld of family therapy. This shift in practice from individual to family treatment respects the family as a system whose process significantly influences all of the members. Intervention, in order to be effective in strengthening the family system, should be introduced prior to the completion of the formulation of the family system, during the early preparenthood period---during pregnancy. $(9,17,21,22,28,50)$

During these nine months a family system is being born. Coping mechanisms must be identified and reinforced. Education and creative 1magery regarding parenthood would prepare couples for situations which they have previously never faced. "The benefits of an educetional sequence or program which focuses upon both family theory and practice appear evident." (14)

The realization that self-knowledge and understanding are necessary before one is capable of successfully meeting the demands of parenthood, with its need for maturity and stability, promises to make life better for children and more rewarding for parents. 


\section{CEAPTER III}

A DESCRIPTION OF A MODEL PREPARENTHOOD CONSULTATION FROGRAM

\section{Rationale}

Reviewing the literature on the crisis effects of preparenthood on each individual family member, the narital couple, the single parent and the growing family unit leaves no question regarding the need for preparenthood consultation. The increasing need to reduce maternal anxlety on a large scale in the U.S. Is obvious as research studies prove that this fear causes obstetric complications $(16,17$, $18,72)$, fetal abnormalities $(4,19)$ and the lack of adequate maternal-infant bonding $(37,42,44,45,47)$ which can lead to child abuse. $(10,32,47)$

Paternal anxiety and marital strife have also been statistically 1dentifled as common during preparenthood. (8, $12,25,36,40,53,57,61,67)$ The need for assistance in resolving this phenomenon is shown in the high occurrence of divorce and inadequate family bonding (which creates a feeling of distance within and among family members) (37, $44,51)$. Some authorities suggest the consequences are drus problems, delinquency, psychiatric disorders, violence, crime, and violent infant death at the hands of parents. $(10,32,47,48)$

The Preparenthood Consultation Program (PCP) will aocomplish the distribution of factual information regarding 
the events of pregnancy, labour, chlldbirth and parenthood. The need for this widespread education is documented by research studies. $(1,4,9,20,31,44,50,61,63,66,68,69)$ It w11l attempt to reach the majority of expectant parents early in pregnancy. $(55,66)$ This is necessary because the lack of factual information regarding these events results In the phenomenon of maternal anxiety. $(4,9,10,11,13,39)$ Maternal fear is reduced by education. $(9,20,21,33,49,61,70)$ PCP would, in this way, also reduce obstetric complications $(4,16,17,18,23,72)$ and negative birth experiences $(32,47)$ wh1ch are typical results of maternal anxiety.

By utilizing the services of a specialized social worker, the program will satisfy recommendations for an "outside consultant" (65) for educating parents $(14,50,53$, 55 ) and observing couples in their homes (34). Psychological ad justment in preparing for birth and parenthood is emphasized in the literature $(9,10,21,27,36,53,61)$ and w1ll be accomplished by preparenthood consultation. This emotional preparation w1ll reduce paternal anxiety, as well as maternal stress.

Preparenthood consultation will reduce the widespread phenomenon of fear, guilt, lack of confidence and disappointment frequently experienced during this stage of life through educated preparation and guided projection into parenthood. It w1ll reduce the occurrence of paternal al1enation $(8,12,21,25,27,36,40,53,58,61,67)$ by including the father in discussion of the events of pregnancy, b1rth and 
early parenthood, thus, educating hIm and encouraging his active participation in these events.

This proposed program model specifies therapeutic intervention that takes advantage of the progressive forces of health and growth within the marital couple and the fam1ly unit. $(40,50,57)$ Preparenthood is a maturational crisis phase of I1fe. Maturational or developmental crises phases of $11 \mathrm{fe}$ are periods when people are more eager to reach out for guldance and more willing to change. $(22,50$, 53,55) During these developmental stages, parents are more able to integrate, maintain and utilize successively (and successfully) the personal, marital and family system 1mprovements they acquire.

PCP will assist the couple in coping with marital stress during preparenthood which is a common crisis of this period. $(16,17,18,21,33,34,53,61)$ The need for enhanced marital communication is supported by the research. $(5,9,49,59,61,63)$ Consultation will accomplish improved communications and reduce feelings of emotional distance within the family unit. $(32,44,48,49)$ The Preparenthood Consultation Program will teach family process, problemsolving and decision-making sirills which will be of great assistance throughout family 11fe. The PCP facilitates the family as it emerges into a new system.

Research studies show the necessity of a preventative approach to family and marital therapy. $(10,15,24, ? 8,32,47$, $48,50)$ These findings stress the consideration of the 
psychosocial needs of the family $(5,4,63)$ especially in cases of regionalized care, retarded or handicapped infants, complicated births and the need for increased emotional support of the single parent. (63) The PCP will offer this sipport for the family during the crisis perlod of coping with prenatal and postpartum problems. $(1,4,12,19,21,28,36,46,61,67$, 72) It will offer resource referral and provide follow-lip support $(56,62)$ during the first $s i x$ weeks of parenthood, which is greatly needed. $(2,54,56,61,62,63,66)$

The Preparenthood Consultation Program is a preventative approach to ramily therapy and to physical, mental and emotional health care during preparenthood. The program aspires to promote and reinforce the concept that pregnancy is a natural condition; that childbirth is a natural event In a woman's Iffe; and that parenthood is a natural state of human life. If a woman and the family will take reasonably good care of themselves (herself and 1tself) and develop and maintain within themselves a wholesome mental att1tude, pregnancy, chlldbirth and parenting will proceed to their natural and logical conclusion, with the usual result of a healthy mother, infant, and family (and that w1thout any interference and with only a negligible need for professional attention).

\section{Concepts}

The program will convey the importance of good nutr1tion and physical care. (6́3) Participants w1ll learn exerclses and the principles of a good nutritional diet. They 
w11l learn to appreciate the importance of the father's active role in pregnancy and early parenthood. $(5,7,8,9,21$, $33,36,40,42,53)$ Couples w11l learn of the positive effects that involved fathers can have on newborns $(21,28,33,37,46$, $47,51,58)$ and the intimate effects an understanding father can have in relation to the mother's well-belng during pregnancy and the immediate after birth per1od $(33,36)$.

Preparenthood consultation w1Il prepare fathers for the birth experience as research studies point out the distinct need for this preparation. $(9,21,53)$ The program will convey to participants the benefits of the husband's presence at labour and delivery. His presence has been proven to reduce maternal fear and pain at the time of labour and birth. $(6,8,9,21,33,66)$

The PCP will convey the 1mportance of normal, unrned1cated, birth experiences $(4,9)$ where the mother takes an active role in labour and delivery $(9,11,13,16,20,31,39,69$, 72). Particlpants w1ll learn methods of coping with the labour contractions (11), especially breathing and relaxation, and, thereby, learn to reduce maternal anxlety and pain during delivery. This knowledge increases mothers. sense of power and control during the experience. (9) The literature recommends the need for patients. sense of power and control (14) in accomplishing a positive experience.

The program will emphasize the great 1mportance of maternal-infant bonding in the immediate after birth period and, thus, encourage early Intimate contact with the new 
baby. $(10,20,32,37,42,44,45,51,63)$ : Preparenthood consultation will convey the necessity of developing good communication skills (34) and teach participants constructive family process. Couples will learn how their individual childhoods effect their marital relationship and to resolve the negative patterns of their nuclear families. (50) Participants will explore their preconceptions, learn how to resolve unrealistic expectations, assume responsibility for themselves, negotlate differences and conflict, develop coping mechanisms, discover mutually satisfying ways to nurture and support one another, and cultivate a responsive and caring family environment. $(40,50)$

Format and Objectives

The program dwells upon natural orinclples in group discussion. Wherever possible and upon their specific applications with the individual family units. The PCP is designed to unfold the processes of regeneration to promote confidence in them. It enlightens expecting parents regarding situations which they may encounter during preparenthood and assists them with developing mechanisms for coping with this new style of ilfe.

The program avalls expecting couples of education and counseling services on a monthly basis for the eleven months during which the new family is forming. It includes six classes two hours in length given to groups of expecting parents and flve two hour sessions with ench family in their home. Ideally, discussion groups will be feasible with 
six couples. The private family counseling sessions in the home will involve only the one family. The social worker will, thus, be involved with any given group of six couples a total of 12 hours in group discussion and 60 hours in the fleld meeting with exch individual couple in their home. The materials needed for such a program are relatively few. The main needs being a large room with a comfortable carpet to sit on and appropriate posters for visual alds. A brief description of the courses follows accompanied by the specific course objective:

Class 1 Nutrition (Group) a discussion of principles of good nutrition including the effects of vitamins, minerals, protein and carbohydretes on the body; food and herb sources for each of them; and the importance of a positive mental attitude as our thoughts and words are glso foods for our bodies to digest.

OBJECIIVE: to enhance maternal, infant, and family health.

Class 2 Body Awareness (Group) postural anzlysis and experlences with relaxation, tension control, bre?thing, prenatal soga and other specific pregnancy and postpartum-related exercises.

OBJECTIVE: to prepare women physically for the lobour and birth experience and to introduce healthy physical practices for later life.

Class 3 Phys 10logy and Anatomy of Pregnancy (Group) a discussion of the anatomy of pregnoncy, the process of procreation and the stages of fetil development.

OBJECTIVE: to 1ncrense understending of the physiologicel mechonics of pregnerncy, libour and birth and, thus, reduce maternal anxlety regrading these experiences.

Class 4 The Preparenthood Transition (Family) exploring the body changes, hormonal changes, emotional changes and potential communication blocks of this orisis period. (This class also explores the effects of pregnancy and early postpartum on existing siblings and the family unit.)

OBJECTIVE: to develop mechanisms for coping with the changes pregnancy and parenthood bring to the female body and the marital relationship, and to est blish and reinforce the maintaining of open communication, ac ive listening and 
the appreciation of individual differences.

Class 5 Fatherhood (Family) a discussion of the importance of the father's role in the prenatal period, labour, del1very and early parenthood and the transition changes---sexual, financili, mental and emotional---which fathers sometimes experience durinz preparenthood.

OBJECTIVE: to reduce paternal anxlety and the occurrence of the allenated father syndrome and to make clear the great benefits of the father's participation in early parenthood.

Class 6 parenthood (Family) an introduction to the family as a system by experiencing family system process, exploring the process of the families of origin and projecting into family life and child care.

OBJECTIVE: to promote knowledgeable and responsible porenting attitudes and skills; to establish constructive family problem-solving and decision-making; to reduce anxiety regarding the events, emotions, circumstances and situations which may be encountered upon the advent of parenthood; and to reduce marital conflict during preparenthood.

Class 7 Postpartum Care (Group) a discussion of immediate afterbirth care of mother and infant, bonding, brenstfeeding and good infant nutrition.

OBJECTIVE: to enhance the Immediate postpartum experience, family bonding and infont health.

Class 8 Labour and Birth (Group) information about the physlological mechanisms of 13 bour and childbirth and the father's supportive role.

OBJECTIVE: to reduce anxiety regarding labour and delivery and to promote a supportive paternal childbirth coach.

Class 9 What If? (Group) discussion of pregnancy and childbirth complications, childbirth drugs, stilibirth, and the birthing mother's rights.

OBJECTIVE: to resolve mythical attitudes regarding 1 sbour and birth; to allow for emotions of sorrow and disappointment to be thought through and constructively worked with; and to educate parents as to their legal rights.

Class 10 Setting Orientation (Family) an orientation to the planned birth location. This may be a postpartum followup home visit if the newborn has already arrived.)

OBJECTIVE: to reduce anxiety by introducing couples to the planned birth environment.

Class 11 Home Visit (Family) follow-up home visit. OBJECTIVE: to assess famlly well-belng, answer any questions, offer additionil assistance and resource referral. 


\section{CHAPTER IV}

\section{CONCLUSION}

This research practicum has explored the crisis nature of the period in fomily life beginning at conception and lasting through six weeks postpartum. It has shown the effects of preprenthood on the mother, the father, the infent, the marital relationship and the family system. It defines the preparenthood period as a crucial transition stage of family, individual and marital life, $z$ period of extreme crisis. $(11,22,25,36,40,50,53,58,61,67)$ The study documents the need for support and sssistance in the form of education and counseling during this important phase of $11 \mathrm{fe}$.

A model Preparenthood Consultat,ion Program has been outlined and is intended to meet the needs as identified by the review of the 11terature. This suthor believes that this program, offered to all segments of the population, w1ll reduce maternal anxiety, obstetric complications, inadequate bonding, paternal anxiety, the allenated father syndrome, poor martili relations and destructive family process.

Consultation during this period of upheaval could benefit not only the individuals, their m?rriages and fam1Iles, but all of society by enhincing interperson l and interfamillil relations, increasing person 1 self-confidence 
and capacity to express self-worth, and by developing problem-solving, decision-making and coping mechanisms withIn the family system. Through this consultation, soc1al problems of child abuse, violent infant death, and the feeling of distance and alienation, which can cause many other forms of social devioncy, will be reduced.

Researchers wri亡e,

There is a great need for a care system that provides continuity for the fainily unit not only through the pregnancy cycle and inpatient experience but into the postpartum experience as well. (6?)

A therapeutic process designed to guide toward and support the resolution of the crisis (preprenthood) or mastery of stress will relesse natur?l growth tendencles. It will strengtien the ego of $\approx 11$ people, regardless of personality structure and the specifics of psychopathology. (55)

The preventative approach to treatment will be the major trend in the future with respect to all aspects of social service. Implementation of this, the Preparenthood Consultation Program, approach is not only loglcal, but vitally necessary, now.

The independent family, living within its own four walls, self-sufficlent and taking complete responsibility for its members in sickness and health, is the ideal family unit in the modern world... The integrity of a society rests with the integrity of family life. Serene and happy children, children who do not need to spend their lives making up for defects in their upbringing, have the freedom to choose whether to found a family or to devote themselves fully to the kinds of activities that make high civilization possible...(44)

The transformation of $3 \mathrm{w}$ y of 11 fe and its fruition in creativity depend on the existence of $a$ kind of family in which children are reared to percelve themselves and all others as full human beings and to see the wider significance esch individuni's 
gift may have for the vorld. community. In this way change 1tself reaffirms the stabiiity of the family's task. (44) 
References cited

1. Adamsons, K.: Maternal sympathetic nervous system and fetal homeostasis, Contemporary Obstetrics and Gynecology, Vol. 5, No. 40, 1974.

2. Andersen, J., R N., M S : A clarification of the lamaze method, Journal of obstetrics, Gynecology and Neonatal Nursing, Vol. 6, No 2, March-April, 1977.

3. Arms, S., Immaculate Deception, Houghton-Mifflin, Boston, 1975.

4. Ascher, B.: Maternal anxiety in pregnancy and retal homeostasis, Journal of obstetric, Gynecologic and Neonatal Nursing, Vol. 7, No. 3, May-June, pp.18-21, 1978.

5. Auerswald, E.: A systems dilemma, Family Process, Vol. 8, pp. $211-234,1976$.

6. Bean, A., Methods of Childbirth, New York, Doubleday and Company, 1972 .

7. Benson, A., Fatherhood, A Soc10logical Perspective, New York, Doubleday and Company, 1974.

8. Biller, H. and Meredith, D., Father Power, New York, Doubleday and Company, 1975.

9. Bradley, R., Husband-Coached Childbirth, Harper and Row, New York, 1974.

10. Bricklin, A., Motherlove: The Book of Natural Childrearing, Running Press, Phlladelphia, Penn, 1975.

11. Buxton, C.L., A Study of Psychophyslcal Methods for Relief of Childbirth Pain, Philadelphia, W.S. Saunders Company, 1962 .

12. Cavenar, J.O., Jr., M.D. and Butts, N.T., M.D.: Fatherhood and emotional iliness, American Journal of Psychlatry, Vol. 134, pp. 429-431, Apri1 1977.

13. Chertok, L., Psychosomatic Methods in Painless Childb1rth, New York, Pergamon Press, 1959.

14. Chertok, L.: Psychosomatic methods of preparation for childbirth, American Journal of Obstetric Gynecology, Vol. 98, pp.698-707, 1957 . 
15. Dalley, D., D.S.W.: The pregnant male, Journal of Sex Education and Therapy, pp. 43, 1977.

16. Davids, A., DeVault, S. and Talmadge, M.: Anxiety, pregnancy, and childbirth abnormalities, Journal of Consulting Psychology, Vol. 25, pp.74-77, 1961(a).

17. Davids, A., DeVault, S. and Talmadge, M.: Psychologleal study of emotional factors in pregnancy, Psychosomatic Medicine, Vol. 33, pp 93, 1961(b).

18. Davids, A. and DeVault, S.: Maternal anxiety during pregnancy and childbirth abnormalities, psychosomatic Mediclne, Vol. 24, pp.464, 1962.

19. Davids, A., Holden, R.A. and Gray, G.B.: Maternal anxiety during pregnancy and adequacy of mother and child adjustment eight months following childbirth, Child Development, Vol. 34, pp.993, 1963.

20. Doering, S.G. and Entwisle, D.'R.: Preparation during pregnancy and ability to cope with labor and delivery, American Journal of Orthopsychlatry, Vol. 45, pp.825837, October, 1975.

21. ElSherif, C., McGrath, G. and Smyrski, J.: Coaching the coach, Journal of Obstetric, Gynecologic and Neonatal Nursing, Vol. 6, No. 36, March-April, 1977.

22. Erikson, E.: Identity and the life cycle, Psychologlcal Issues, Vol. 1, 1959.

23. Erickson, M.T.: Relationships between psychological attitudes during pregnancy and complications of pregnancy, labour, and delivery, proceedings of the 73rd Annual Psychological Assoclation, pp.213-2.14, 1965.

24. Fabrega, H., Disease and Soc1al Behavior, Cambridge, Mass.: MIT Press, 1974.

25. Fasteau, E., The Male Machine, Doubleday and Company, New York, 1974.

26. Ferreira, A.J., Prenatal Environment, Springfield, I11., Charles C. Thomas, 1969.

27. G1lder, G., The Naked Nomads, Times Books, New York, 1974. 28. Greenberg, M. and Morr1s, N.: Engrossnent: the newborn's impact upon tine f'ather, American Journal of Ortnopsychlatry, Vol. $44, \mathrm{pp} .520-531,1974$. 
29. Grossman, M., M.D.: Infants separated from mothers are more ilkeiy to be battered chlldren, National Enquirer, June $30,1974$.

30. Haire, D., The Cultural Warping of Childbirth, Monograph Internat Ional Childbirth Education Association.

31. Halstead, J. and Fredrickson, T.: Evaluation of a prepared chlldbirth program, Journal of Obstetric and Gynecological Nursing, pp. 39-42, May-June, 1978.

32. Helfer, R. and Kempe, C., The Battered Child, University of Chicago Press, Chicago, III., 1968.

33. Henneborn, W.J. and Cogan, R.: The effect of husband participation on reported pain and probability of medication during labour and birth, Journal of Psychosomatic Research, Vol. 19, No. 3, pp.215-222, 1975.

34. Hott, J.R.: The crisis of expectant fatherhood, American Journal of Nursing, Vol. 76 , pp 1436-1440, September, 1976.

35. Joffee, J., Prenatal Determinants of Behav1or, New York, Pergamon Press, 1969.

36. Jones, T.: Being a pregnant male is no bed of roses, Mental Health Association in Oregon Newsletter, Vol. 24, No. 4, Fall, 1978.

37. Klaus, M.H. and Kennell, J.H., Maternal-Infant Bonding: The Impact of Early Separation or Loss on Family Development, St. Louis, The C.V. Mosby Company, 1976.

38. Kleinman, A., Eisenbers, I. and Good, B.: Culture, 111ness and care: clinical lessons from anthropologlcal and oross-cultural research, Annuals of Internal Medicine, Vol. 88, pp. 251-258, $19 \overline{78 .}$

39. Klusman, L.: Reduction of pain in childbirth by alleviation of anxiety during pregnancy, Journal of Consultins and Clinical Psychology, vol. 43, pp.162-165, Apr11, 1975.

40. LeNasters, E.E., Parents In Modern Amer1ca, Homewood, Ill., Dorsey Press, 1970.

41. Levande, D.: Family theory as a necessary component of family therapy, Soc1al Casework, Vol. 57, pp.291-295, May, 1976.

42. Macfarlane, A., The Psychology of Childbirth, Cambridge, Mass., Harvard University Press, 1977. 
43. Mahler, M., Pine, F, and Bergman, A., The Psycholog1cal Birth of the Human Infant, Basic Books, New York, 1975.

44. Mead, M., Fam11y, MacM11lan Company, New York, 1965.

45. Montagu, A., Touching: The Human Signigicance of the Skin, Harper and Row, Columbia University Press, 1971.

46. Parke, R.D. and Sawin, D.B.: Fathering: 1t's a major role, Psychology Today, Vol. 11, pp.108-112, November, 1977 .

47. Peterson, G.H., M.S.S.W. and Mehl, I.E., M.D.: Studies of psychological outcome for various childbirth alternatives, 21 st Century obstetrics Now!, edited by Stewart, Chapel Hill, N.C., Nat'I Assoc of Parents and Professionals for Safe Alternatives in Childbirth, Inc.

48. Prescott, J.: Infants need early touching, National Enquirer, September 15, 1974.

49. Pollinger, A., Medicine, Soctal Pollcy and The Family, Doubleday and Company, New York, 1977.

50. Rhodes, S.: Developmental approach to the I1fe cycle of the family, Soc1al Casework, Vol 58, pp.301-311, May, 1977 .

51. Richards, $M_{1}$ : The one-day-old deprived child, New Scientist, March 28, 1974.

52. Richardson, S.A. and Guttmocher, A.F., Childbearing: Its Soc1al and Psychological Aspects, Baltimore, Md., W11liams and Wilkins, 1967 .

53. Richman, J., Goldthorp, Y.O. and Simmons, C.: Fathers in labour, New Socletr, Vol. 34, No. 680, pp.143-145, october 16,1975 .

54. R1sing, S.S., R.N.: The fourth stage of labor: family integration, American Journal of Nursins, Vol. 74 , pp. 870-874, Nay, 1974.

55. Rosenbers, B.: Planned short term treatment in developmental crisis, Soc121 Casework, Vol. 56, pp.195-204, April, 1975.

56. Rubin, R.: Birth, parenting and nurturing, American Journal of Nursing, Vol. 75, pp.1679-1714, October, 1975. 
57. Russell, B. and Schild, S.: Pregnancy counseling with college women, Social Casework, Vol 57, pp.324-3?.9, May, 1976.

58. Salk, I.: Early role of fathers in care of bables urged, Los Angeles Times, June 15, 1972.

59. Selig, A.: The myth of the mult1-problem family, American Journal of Orthopsychiatry, Vol. 46, pp. 526 532, Ju1y, 1976.

60. Sobel, D., Ways of Health, Harcourt Brace Jovanovich, New York and London, 1979.

61. Stichler, J.F., Bowden, M.S. and Reimer, E.D.: Pregnancy: a shared emotional experience, The American Journal of Maternal and Child Nursing, Vol. 3, pp.153-157, MayJune, 1978.

62. Stranik, M. and Hogberg, B.: Transition into parenthood, American Journal of Nursing, Jol. 79, January, 1979.

63. Sugarman, M., M.D., Paranatal influences of maternalinfant attachment, American Journal of Orthopsych1atry, Vol. 47, pp.407-421, July, 1977.

64. Tanzer, D.R.: The psychology of pregnancy and childbirth. Unpublished doctoral dissertation, Brandeis University, 1967.

65. Ward, C. and Ward, F., The Home B1rth Book, Inscape Publishers, Washington, D.C., 1976.

66. Watson, J., R.N., B.S.N., M.S., PhD: tho attends prepared childbirth classes? a demographic study of Childbirth Educetion Assoc1ation classes in Rhode Island, Journal of Obstetrics, Gynecology and Neonatal Nursing, Vol. 6, pp.36-39, Niarch-April, 1977.

67. White, M.A.: Obstetricians role in postpartum mental iliness, Journil of the American Medical Association, No. 165,1957 .

68. Whitley, N., C.N.M.: A comparison of prepared childbirth couples and conventional prenatal class couples, Journal of Obstetric, Gynecologic and Neonatal Nursing, Vol. 8, No. 2, pp.109-111, March-April, 1979.

69. Wilimuth, R., M.D., Weaver, L., PhD., and Borenstein, J., R.N.: Satisfaction with prepared chlldbirth and locus of control, Journil of Obstetric ind Gynecolos 1c?l Nursing, pp. 33-37, 197?. 
70. Yamamoto, K.J. and KAnney, D.K.: Pregnant women's ratings of different factors influancing psycholog:cal stress during pregnancy, Psychological Reports, Vol. 39, pp.203-214, August, 1976.

71. ---: Sex in pregnancy, Parents Centres, pp.10-11, June, 1974.

72. Zucherman, M., Nurnberger, J.I., Gardiner, S.H., Vendeveer, J.M., Barrett, G.H. and den Breeljen, A.: Psychological correlates of somatic complaints in pregnancy and difficulty in childbirth, Journal of Consulting Psychology, Vol. 27, pp.324-329, 1963. 